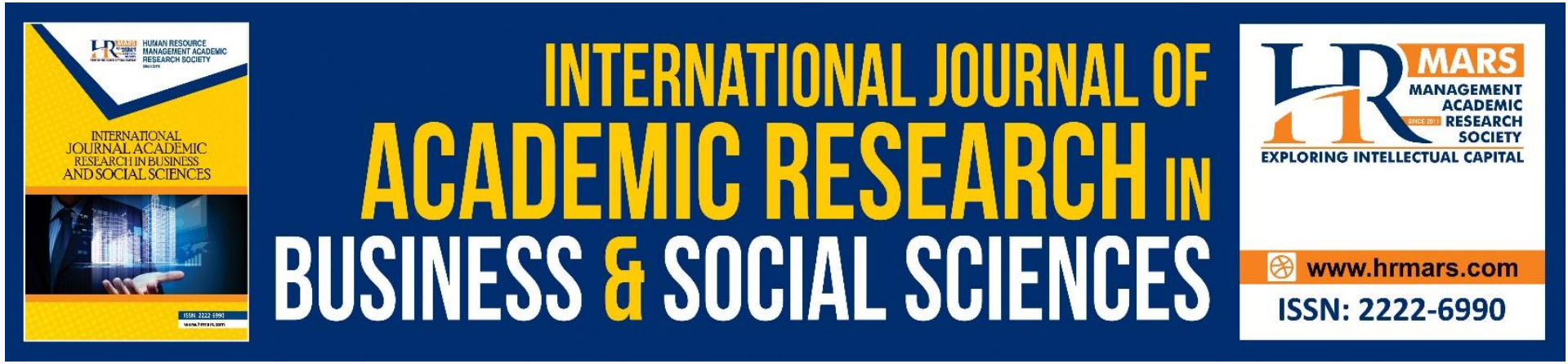

\title{
Enriching Student Knowledge on Sustainable Forest Management Practices by Forestry Professionals: A Look into the Generic Structure Potential of Malaysian Forestry Annual Reports
}

\section{W. F. W. Wan Fakhruddin, A. Saidalvi, Y. Hanafi Zaid, H. Hassan}

To Link this Article: http://dx.doi.org/10.6007/IJARBSS/v11-i7/10542

DOI:10.6007/IJARBSS/v11-i7/10542

Received: 11 May 2021, Revised: 18 June 2021, Accepted: 12 July 2021

Published Online: 28 July 2021

In-Text Citation: (Fakhruddin et al., 2021)

To Cite this Article: Fakhruddin, W. F. W. W., Saidalvi, A., Zaid, Y. H., \& Hassan, H. (2021). Enriching Student Knowledge on Sustainable Forest Management Practices by Forestry Professionals: A Look into the Generic Structure Potential of Malaysian Forestry Annual Reports. International Journal of Academic Research in Business and Social Sciences, 11(7), 864-880.

Copyright: (c) 2021 The Author(s)

Published by Human Resource Management Academic Research Society (www.hrmars.com)

This article is published under the Creative Commons Attribution (CC BY 4.0) license. Anyone may reproduce, distribute, translate and create derivative works of this article (for both commercial and non-commercial purposes), subject to full attribution to the original publication and authors. The full terms of this license may be seen

at: http://creativecommons.org/licences/by/4.0/legalcode

Vol. 11, No. 7, 2021, Pg. 864 - 880

Full Terms \& Conditions of access and use can be found at http://hrmars.com/index.php/pages/detail/publication-ethics 


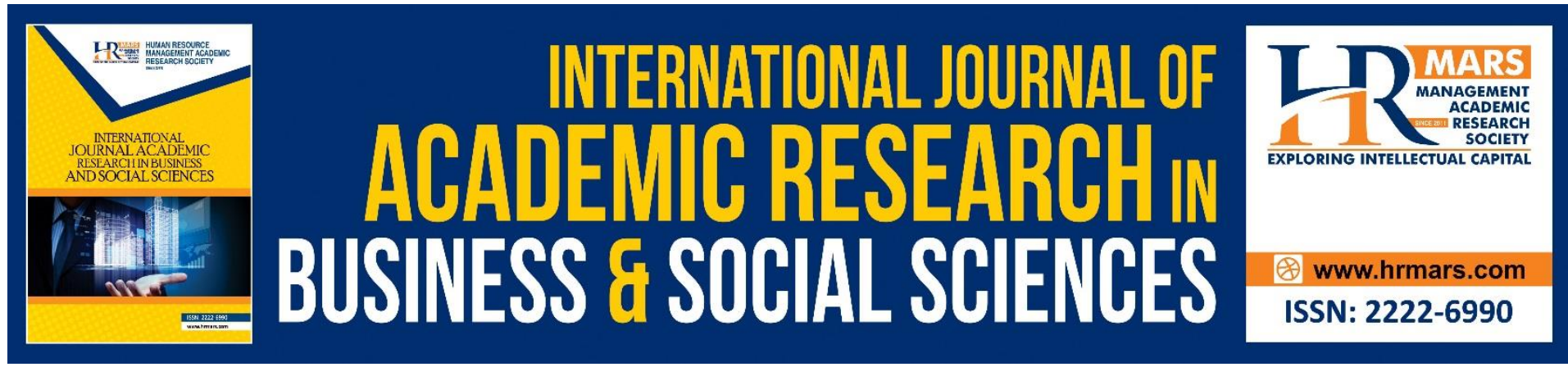

\title{
Enriching Student Knowledge on Sustainable Forest Management Practices by Forestry Professionals: A Look into the Generic Structure Potential of Malaysian Forestry Annual Reports
}

\author{
W. F. W. Wan Fakhruddin ${ }^{1}$, A. Saidalvi ${ }^{2}$, Y. Hanafi Zaid ${ }^{1}$, H. \\ Hassan $^{1}$ \\ ${ }^{1}$ Language Academy, Faculty of Social Sciences and Humanities, Universiti Teknologi \\ Malaysia, Malaysia, ${ }^{2}$ Academy of Language Studies, Universiti Teknologi MARA Johor, \\ Malaysia \\ Email:wanfarah@utm.my
}

\begin{abstract}
Despite the establishment of numerous goals related to sustainable forest management (SFM), including the setting of Goal 15 in the 2015 United Nations' Sustainable Development Goals (SDGs), to date, its implementation is seen to be problematic. Its poor implementation is often associated with ineffective management of forests areas, which poses some challenges for students to understand better the nature of forestry professions and the expectations that come with the responsibility of sustainably managing forest reserves and lands. Analysing the practices and agendas conveyed in the forestry annual report (FAR) is indispensable, especially for forestry students who wish better to understand the forestry profession upon their study completion. This study sets out to identify the generic structure potential for the Year under the Review section of the forestry annual report and its functions in portraying forestry professionals throughout ten years (2009-2018). Document analysis following a Systemic Functional Linguistics perspective on generic structure potential is adopted in this study to identify the obligatory and optional elements included in the forestry annual report as well as the functions of each element observed in the Year under Review section of FAR. The results of the study show that eleven obligatory elements constitute the generic structure of the Year under Review section of the forestry annual report, which is directly related to the ideal SFM practices that contribute to SDG Goal 15 (Protect, restore and promote sustainable use of terrestrial ecosystems, sustainably manage forests, combat desertification, and halt and reverse land degradation and halt biodiversity loss). The establishment of the generic structure potential for the Year under Review section of the Malaysian forestry annual report will help undergraduate forestry students understand the forestry profession's actual practices to equip them with knowledge in real-life settings.
\end{abstract}

Keywords: Generic Structure Potential, Forestry Discourse, Annual Report, Systemic Functional Linguistics, SDG15, Sustainable Forest Management 


\section{Introduction}

The annual report genre is considered a highly specialised text created by and for insiders' (Zanola, 2010:2). It serves broad audiences, including customers, staff, stakeholders and shareholders, to keep them 'informed or updated on the state of affairs, performance or latest progress and developments' (Hussain et al., 2020:237). As one of the more common genres that are produced by forestry professionals, investigating the generic structure potential (GSP) of annual forestry report may instantiate a particular forestry discourse type that can potentially be structured and constructed (Bowcher and Liang, 2016), thus benefitting forestry students who wish to know more about the forestry profession in real settings. In this study, the Malaysian forestry annual report published by the Forestry Department of Peninsular Malaysia (FDPM) was analysed due to its importance in preserving and conserving forests, which help provide a dynamic ecosystem that is crucial for humankind (Katila et al., 2020). Since management of forests has a profound impact on biodiversity, how they are managed, and issues concerning forest management thus need to be addressed and uncovered systematically. While an investigation of forest development discourse has been established (Leipold, 2014), understanding its emergence, dynamics, and impacts may be a little complex considering that these concepts' boundaries are not easily recognisable (de Jong et al., 2017).

Malaysia is among the essential remaining natural forests globally and is also the world's largest supplier of tropical sawlogs, sawn-wood and veneer and the second-largest supplier for tropical plywood (ITTO, 1999). In Malaysia, natural forest resources are perceived to be important and valuable resources that contribute significantly to the country's economy and environmental wellbeing. The vital role that forests play as a balance mechanism for environmental, social and economic stability must therefore be maintained and achieved to provide benefits to the country and the future. In the local context, research on forest management, its resources and forestry community practices have been conducted by those from the forestry discipline either by forestry professionals or by graduate students from the faculty of Forestry. These studies mainly focused on technical and statistical accounts of forest resources in Malaysia which include looking into forest harvesting practices (Islam et al., 2010), illegal logging situations in Malaysia (Gani, Wahab and Rasat, 2013), developing an expert system technology for decision-making in forest resources management (Zukki, Manaf and Samah, 2010) and the scenario of sustainable development and forest resources management (Muda, Hamat and Yusoff, 2009).

This study which analysed the Year under Review section of the annual forestry report genre issued by FDPM from 2009 to 2018, represents a type of professional genre representing how professionals produce language with specialist training to get something done in the workplace (Kong, 2014). As noted by Kong (2014), the language used by professionals plays a significant role in socialising their professional roles and identities and acts as 'a banner of identity' (Wenger, 1998). The study is concerned with a linguistic representation of professional forestry annual report in the Malaysian context drawing from a Systemic Functional Linguistics (henceforth SFL) perspective to explore the generic structure of forestry annual report to investigate the communicative purpose of its structural elements. This paper examined ten editions of the Year under Review section of the Malaysian forestry annual reports published by the Forestry Department of Peninsular Malaysia to generate the GSP for Malaysia forestry annual report. It is believed that no attempt has been made by those in the 
local context to investigate professional forestry text, and none so far has attempted to investigate the forestry annual report genre from a linguistic perspective. Since Malaysian forests are part of tropical forests in Southeast Asia and that FDPM is given the mandate to administer, manage and protect forest areas in Peninsular Malaysia, this study contributes to insights on how forest-related agendas are disseminated and informed through the forestry annual report.

\section{Literature Review}

\section{Generic Structure from a Systemic Functional Linguistics (SFL) Perspective}

SFL is a linguistic theory that views language as a system of meaning-making resource whereby language and the context in which it is used are highly reliant 'through which language shapes, and is shaped by the contexts in which it is used' (Schleppegrell, 2012: 21). Hasan (1985:52) laments that a text can be characterised into two types of 'unity'; unity of texture and unity of structure. The latter is summed up by the generic structure potential, which concerns the meaning of a particular genre's structural elements concerning its contextual features (Bowcher and Liang, 2016).

Generic structure concerns the development of the text, which is surrounded by the given context.

The generic structure analysis is valuable for more strategic, purpose-driven genres where researchers need to look for staging when analysing texts and interactions (Fairclough, 2003). However, Fairclough (2003) cautions that researchers should bear in mind that they cannot always find genres organised in a clear generic structure. Nevertheless, genre analysts constantly seek to explore texts to explain their regularities of purpose, form and situated social action (Malmklæj, 2009). Paltridge (1994) asserts that there are various ways of identifying stages of a genre based on the content of text which includes i) structural paragraphs (Longacre, 1992), ii) macro- and micro-structures (van Dijk, 1977), iii) schematic structure (Martin, 1984), iv) generic structure potential (Hasan, 1985) and iv) moves and steps (Swales, 1990). In SFL, genre is perceived to be the cultural purpose of texts achieved through a genre's structural and realisation patterns (Eggins, 2007) and that it is a 'staged, goaloriented and purposeful social activity' (Martin, 1984:25). The genre following the SFL approach typically involves identifying social purpose as represented in the generic structural elements and staging possibilities within a genre (Eggins and Martin, 2007). Thus, SFL sets out to examine the distinctive stages or moves evident within a text along with its patterns of lexical, grammatical and cohesive choices that help to accomplish the function in each of the genre stages (Rothery, 1996).

An exploration of the nature and functions of genre has been attempted by Halliday in a few of his works and has also argued that 'in order to give a complete characterisation of texture, we should make reference also to 'generic' structure, the form that a text has as a property of its genre' (Halliday, 1978:61). In response to this, Hasan defines the concept of genre as 'type of discourse' and initiated the investigation of its text structure (Halliday \& Hasan, 1985 ) and proposes a model of generic analysis called the generic structure potential (henceforth GSP). GSP is both a formula and a model that allows a description and specification of a genre's text structure as well as the sub potential for the process of a given text type through the identification of the total range of optional, obligatory and possible iteration of elements and their order in a text (Hasan, 1985). According to Hasan (1985), the 
GSP and the CC are closely connected, which 'permits statements about the text structures' to be made (Halliday and Hasan, 1985:56). Prediction about a text structure can be made using CC concerning:

\author{
i. What elements must occur \\ ii. What elements can occur \\ iii. Where must they occur \\ iv. Where can they occur \\ v. How often can they occur (Hasan, 1985:56, emphasis in original)
}

GSP is concerned with the possibility of text structure of a particular genre, including the expression of the total range of obligatory and optional elements and their order. Thus, this paper investigates the elements and generic structure of the forestry annual report genre, focusing on the Year under Review section.

\title{
Studies on Forestry Genre from a Linguistic Perspective
}

Little is known about forestry-related genre, and at present, no studies have been conducted investigating forestry-related genre from an SFL perspective. Forestry genres, in general, have received very little attention from a linguistic perspective despite the field being one of the most valuable resources for a country in general and Malaysia in particular in the hope of sustaining a nation's natural resources, economy and ecology. Only a few recent studies (Joseph and Lim, 2018; Friginal, 2013; Joseph, Lim and Nor, 2014) have focused on the forestry discipline from a linguistic perspective. Friginal (2013) conducted a corpus-based study analysing a set of linguistic features (linking adverbials, reporting verbs, verb tenses and passive-active sentence structures) which were chosen based on a corpus of 500 professional forestry research articles in Journal of Forestry, Journal of Forestry Research and three corpora of research reports/ lab reports written by students enrolled in the programme. Although Friginal's (2013) study aimed at investigating the effects of corpus-based instruction on developing students' writing skills instead of analysing how language is used within the context of forestry, the study was able to highlight distinct linguistic features that are present within the corpora analysed in the study. Although Friginal's (2013) study aimed to enhance students' overall writing skills when writing research and lab reports, the study's findings have given new insights on the kind of linguistic features included and expected within the scope of forestry research article genre.

Another study conducted by Joseph, Lim and Nor (2014) was done in the local context. Their study aimed to provide forestry students with an understanding of the rhetorical strategies required in research article introductions in the discipline and facilitate teachers with relevant teaching materials for pedagogical practices in English for Research Purposes (ERP) courses. The study employed Swales' (1990) CARS model following ESP-based genre analysis to analyse the research article introductions of high impact forestry journals with the hope that students enrolled in the forestry programme in Malaysian universities will have access to forms of language needed in the academic world, which will later be assimilated into both the academic and professional discourses. While findings of the studies in Friginal (2013) and Joseph, Lim and Nor (2014) contribute to knowledge on academic forestry texts, findings obtained in the current study aspires to enrich the literature on professional forestry texts 
used in the real world, which are also beneficial for pedagogical and professional practices in the discipline.

\section{Methodology}

This study's data consist of ten forestry annual reports published by the Forestry Department of Peninsular Malaysia (FDPM) from 2009 to 2018. Typically, the Malaysian forestry annual reports issued by FDPM is approximately between 185 and 229 pages. The report is written in Malay and English. In this study, the Year under Review section written in English was chosen to be the focus of the study as the section acts as a summary of the main events or activities carried out throughout the year. The Year under Review section of the forestry annual report is between six and seven pages in length. In this study, a combined total of 88 pages of the Year under Review section was investigated over the ten-year data. To generate the generic structure potential (GSP) for the Year under Review section of the forestry annual report, Hasan's (1984) GSP method is adopted in this study.

This study aims to establish the generic structure of the Year under Review section of the forestry annual report that represents the genre's elements and stages that constitute the genre and how they relate to the genre's overall function and purpose. Hasan's (1984) GSP model considers three classes of phenomena that are visibly indicated; $i$. the status of its functional elements (obligatory, optional), ii. the order of sequence of the functional elements (fixed, etc.) and iii. the possibility of recursion /reiteration for some elements (Hasan, 2014). Additionally, the linguistic realisations of the contextual parameters (field, tenor and mode) 'are predicted by reference to the metafunctional orientation of the lexicogrammar and semantics' (Hasan, 2014: 8). From a genre-analytic perspective, SFL offers a detailed description of the rhetorical functions and linguistic structures. Moreover, SFL relates the contextual dimensions of register/genre to the semantic and grammatical organisation of the language itself that has the potential of developing detailed specifications of the staging structures and realisational features of genres (Ansary and Babaii, 2005).

Table 1 presents the distribution of elements that constitute the Year under Review section of the forestry annual report published by FDPM from 2009 to 2018. 
Table 1. Distribution of elements of the Year under Review section of Forestry Annual Report

\begin{tabular}{|c|c|c|c|c|c|c|c|c|c|c|}
\hline Element & 2009 & $\begin{array}{c}201 \\
0\end{array}$ & $\begin{array}{c}201 \\
1\end{array}$ & $\begin{array}{c}201 \\
2\end{array}$ & $\begin{array}{c}201 \\
3\end{array}$ & $\begin{array}{c}201 \\
4\end{array}$ & $\begin{array}{c}201 \\
5\end{array}$ & $\begin{array}{c}201 \\
6\end{array}$ & $\begin{array}{c}201 \\
7\end{array}$ & $\begin{array}{c}201 \\
8\end{array}$ \\
\hline Forest Resources & $\checkmark$ & $\checkmark$ & $\checkmark$ & $\checkmark$ & $\checkmark$ & $\checkmark$ & $\sqrt{ }$ & $\checkmark$ & $\checkmark$ & $\checkmark$ \\
\hline $\begin{array}{l}\text { Forest Resource } \\
\text { Management }\end{array}$ & $\checkmark$ & $\checkmark$ & $\checkmark$ & $\checkmark$ & $\checkmark$ & $\checkmark$ & $\checkmark$ & $\checkmark$ & $\checkmark$ & $\checkmark$ \\
\hline $\begin{array}{l}\text { Forest Resource } \\
\text { Development }\end{array}$ & $\checkmark$ & $\checkmark$ & $\checkmark$ & $\checkmark$ & $\checkmark$ & $\checkmark$ & $\checkmark$ & $\checkmark$ & $\checkmark$ & $\checkmark$ \\
\hline $\begin{array}{l}\text { Forest Conservation } \\
\text { and Environmental } \\
\text { Protection }\end{array}$ & $\checkmark$ & $\checkmark$ & $\checkmark$ & $\checkmark$ & $\checkmark$ & $\checkmark$ & $\checkmark$ & $\checkmark$ & $\checkmark$ & $\checkmark$ \\
\hline $\begin{array}{l}\text { - Coastal forest } \\
\text { conservation }\end{array}$ & $\checkmark$ & $\checkmark$ & $\checkmark$ & $\checkmark$ & $\checkmark$ & $\checkmark$ & $\checkmark$ & $\checkmark$ & $\checkmark$ & $\checkmark$ \\
\hline $\begin{array}{l}\text { Forest biological } \\
\text { diversity scientific } \\
\text { expedition }\end{array}$ & $\checkmark$ & $\checkmark$ & $\checkmark$ & $\checkmark$ & $\checkmark$ & $\checkmark$ & $\checkmark$ & $\checkmark$ & $\checkmark$ & $\checkmark$ \\
\hline $\begin{array}{l}\text { Forest Harvesting } \\
\text { - } \quad \text { Area Licenced for } \\
\text { Harvesting }\end{array}$ & $\begin{array}{l}\checkmark \\
\checkmark\end{array}$ & $\begin{array}{l}\checkmark \\
\checkmark\end{array}$ & $\begin{array}{l}\checkmark \\
\checkmark\end{array}$ & $\begin{array}{l}\checkmark \\
\checkmark\end{array}$ & $\begin{array}{l}\checkmark \\
\checkmark\end{array}$ & $\begin{array}{l}\checkmark \\
\checkmark\end{array}$ & $\begin{array}{l}\checkmark \\
\checkmark\end{array}$ & $\begin{array}{l}\checkmark \\
\checkmark\end{array}$ & $\begin{array}{l}\checkmark \\
\checkmark\end{array}$ & $\begin{array}{l}\checkmark \\
\checkmark\end{array}$ \\
\hline Production & $\checkmark$ & $\checkmark$ & $\checkmark$ & $\checkmark$ & $\checkmark$ & $\checkmark$ & $\checkmark$ & $\checkmark$ & $\checkmark$ & $\checkmark$ \\
\hline Wood-based Industries & $\checkmark$ & $\checkmark$ & $\checkmark$ & $\checkmark$ & $\checkmark$ & $\checkmark$ & $\checkmark$ & $\checkmark$ & $\checkmark$ & $\checkmark$ \\
\hline Socioeconomic & $\checkmark$ & $\checkmark$ & $\checkmark$ & $\checkmark$ & $\checkmark$ & $\checkmark$ & $\checkmark$ & $\checkmark$ & $\checkmark$ & $\checkmark$ \\
\hline $\begin{array}{l}\text { Contributions } \\
\text { - Timber Products } \\
\text { Trade }\end{array}$ & $\checkmark$ & $\checkmark$ & $\checkmark$ & $\checkmark$ & $\checkmark$ & $\checkmark$ & $\checkmark$ & $\checkmark$ & $\checkmark$ & $\checkmark$ \\
\hline $\begin{array}{l}\text { - Forest Revenue } \\
\text { Collection to the }\end{array}$ & $\checkmark$ & $\checkmark$ & $\checkmark$ & $\checkmark$ & $\checkmark$ & $\checkmark$ & $\checkmark$ & $\checkmark$ & $\checkmark$ & $\checkmark$ \\
\hline $\begin{array}{l}\text { State Government } \\
\text { - Employment in the } \\
\text { Forestry Sector }\end{array}$ & $\checkmark$ & $\checkmark$ & $\checkmark$ & $\checkmark$ & $\checkmark$ & $\checkmark$ & $\checkmark$ & $\checkmark$ & $\checkmark$ & $\checkmark$ \\
\hline $\begin{array}{l}\text { Human Resource } \\
\text { Development }\end{array}$ & $\checkmark$ & $\checkmark$ & $\checkmark$ & $\checkmark$ & $\checkmark$ & $\checkmark$ & $\checkmark$ & $\checkmark$ & $\checkmark$ & $\checkmark$ \\
\hline
\end{tabular}

\section{Data Analysis}

In this study, the obligatory, optional and recursive elements in the Year under Review section of the forestry annual reports are determined to devise its GSP. Ten sets of the Year under Review section of the forestry annual report gathered from 2009 to 2018 were analysed. After determining the type of elements (obligatory/optional/recursive), each element's general function is summarised. Findings concerning the elements, their structure and general function are presented in the following section.

\section{Results}

Based on the analysis conducted, the GSP of the Year under Review section of the forestry annual report has been successfully devised. It forms a linear pattern of both the sequence of elements and recognisable staging possibilities of the elements. Therefore, the GSP of the 
Year under Review section of the forestry annual report is formulated, as shown in Figure 1. Expressed linearly, the GSP of the Year under Review section of the forestry annual report can be represented as:

Forest Resources $(\mathrm{FR})^{\wedge}$ Forest Resource Management $(\mathrm{FRM}) \wedge$ Forest Resource Development $($ FRD) $\wedge$ Forest Conservation and Environmental Protection (FCEP) ^ [Coastal Forest Conservation $(\mathrm{CFC}) \wedge$ Forest Biological Diversity Scientific Expedition (FBDSE) ] $\wedge$ Forest Harvesting (FH) [Area Licensed for Harvesting] ^ Production (P)^ ${ }^{\wedge}$ Wood-based Industries (WI) $\wedge$ Socioeconomic Contributions (SC) [Timber Products Trade $\wedge^{\wedge}$ Forest Revenue Collection to the State Government ^ Employment in the Forestry Sector] ^ Human Resource Development (HRD)

No round bracket : Indicates obligatory elements

$\wedge$ Carat sign : Indicates relative sequence

[ ] Carat sign : Enclose the boundaries of the sub-elements. Indicated by enclosing the relevant elements

Figure 1. The Generic Structure Potential of the Year Under Review section of Forestry Annual Report

Figure 1 is a linear representation of the GSP of the Year under Review section of the forestry annual reports in terms of the sequence of stages and their order in the genre analysed in this study. Nine elements constitute the GSP of the Year under Review section of the forestry annual report, which includes: Forest Resources (FR), Forest Resource Management (FRM), Forest Resource Development (FRD), Forest Conservation and Environmental Protection (FCEP), Forest Harvesting (FH), Production (P), Wood-based Industries (WI), Socioeconomic Contributions (SC), and Human Resource Development (HRD) and two sub-elements under FCEP which are Coastal Forest Conservation (CFC), Forest Biological Diversity Scientific Expedition (FBDSE) and three sub-elements under SC which are Timber Products Trade, Forest Revenue Collection to the State Government and Employment in the Forestry Sector. It is found that the genre can be established in a linear form since the staging of the elements found in all ten datasets analysed are obligatory and sequenced identically in each report, and those optional elements are not found in the genre. The ${ }^{\wedge}$ sign indicates the sequence of fixed stages in its order, while the [ ] sign indicates the sub-elements embedded within another element.

To reiterate, the GSP of a genre refers to 'a statement of the structural resources available within a given genre' (Hasan, 1984: 23). This study found that the elements included are obligatory and are arranged in a systematic and sequenced pattern. Thus, it allows the GSP formation for the Year under Review section of the forestry annual report. In terms of the general function each element serves in the forestry annual report, it can be concluded that each element presented are relevant to the concerns of sustainable forest management (SFM) practices that forestry officers employed at the federal and state governments, which reflects the critical concerns of forestry institutions worldwide (Jalilova, Khadka, and Vacik, 2012). The subsequent discussion will focus on the general function of the nine elements represented in the GSP of the Year under Review section of the forestry annual report. 
The first element, the Forest Resources (FR), informs readers about Peninsular Malaysia's total land area and the total percentage of the land area that is gazetted as Permanent Reserved Forests (PRFs). This element is written in short paragraphs, as shown in Excerpt 1.

\section{Excerpt 1:}

At the end of 2010, forested land accounted for 5.86 million hectares or $44.5 \%$ of Peninsular Malaysia's total land area of 13.18 million hectares. Out of this total, 4.92 million hectares or $83.9 \%$, have been gazetted as Permanent Reserved Forests (PRFs) under the National Forestry Act, 1984. These PRFs are managed under the sustainable forest management principles for economic, social and environmental benefits. (Forestry Annual Report 2010:52)

The next element is the Forest Resource Management (FRM), which informs readers of the different types of forest and the policy implemented and practised by FDPM and the state forestry departments. In this element, notification regarding the state forestry departments' policy compliance and certification are also highlighted. Thus, this element allows FDPM to highlight their compliance to sustainable forest management (SFM) practices and the policies they adhered to. Excerpt 2 shows a sample of FDPM compliance with SFM practices.

\section{Excerpt 2: \\ All the eight (8) timber-producing states implementing the forest management certification have undergone surveillance audits. Eight (8) states, namely Johor, Kedah, Kelantan, Negeri Sembilan, Pahang, Perak, Selangor and Terengganu have fulfilled all conditions under the standards and continued to be certified. (Forestry Annual Report 2011:52)}

The third element that constitutes the Year under Review section of the forestry annual report is the Forest Resource Development. In this element, information regarding the government's allocation is announced along with the report on the expenditure by the federal and the state governments through the various programmes and projects conducted within the year. out financial reports and information about events and activities conducted. The information presented under this section is presented in a table form, as shown in Figure 2.

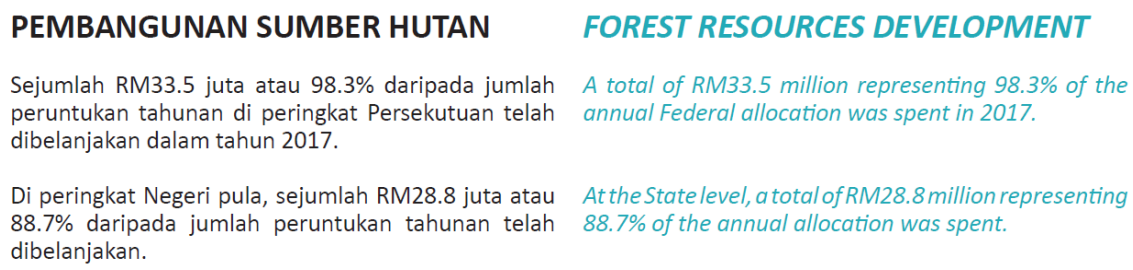

\begin{tabular}{|lccc|}
\multicolumn{1}{c}{$\begin{array}{c}\text { Persekutuan / Negeri } \\
\text { Federal / State }\end{array}$} & $\begin{array}{c}\text { Peruntukan } \\
\text { Allocation }\end{array}$ & $\begin{array}{c}\text { Perbelanjaan } \\
\text { Expenditure }\end{array}$ & $\begin{array}{c}\text { Peratus } \\
\text { Percent } \\
\text { (\%) }\end{array}$ \\
\hline Persekutuan / Federal & $34,083,300.00$ & $33,515,891.21$ & 98.3 \\
\hline Negeri / State & $32,438,133.91$ & $28,781,706.23$ & 88.7 \\
\hline Jumlah / Total & $66,521,433.91$ & $62,297,597.44$ & $\mathbf{9 3 . 7}$
\end{tabular}

Figure 2. Example of the Forest Resource Development element 
The next element of the Year under Review section in the forestry annual report genre is the Forest Conservation and Environmental Protection element. There are two embedded subelements; Coastal Forest Conservation and Forest Biological Diversity Scientific Expedition. Under the Coastal Forest Conservation element, information regarding forestry department programmes is presented, including information on planting projects, awareness campaigns to the society and book or paper publication conducted by the respective forestry departments. An example of the information presented under this element is shown in Excerpt 3.

\section{Excerpt 3:}

A total of 35 awareness campaigns were conducted under this programme throughout the country. This campaign involved various communities with the purpose to enhance public awareness of the importance of coastal forests as well as to instill the spirit of 'common ownership' for environmental wellbeing. (Forestry Annual Report 2014:53)

Another sub-element is the Forest Biological Diversity Scientific Expedition which provides information concerning expedition projects involving forestry officers conducted during the year under review. Activities such as a scientific expedition to the reserved forests and further exploration of other fields, including eco-tourism, archaeology and biological diversity, are presented in this sub-element. An example of the element is presented in Excerpt 4.

\section{Excerpt 4: \\ FDPM had organised one (1) Forest Biological Diversity Scientific Expedition of Bukit Nanas Forest Reserve, Kuala Lumpur. The expedition involved 100 officers from FDPM and researchers from Universiti Putra Malaysia. Studies of various fields regarding ecosystems, biological diversity of flora and fauna, ecology, eco- tourism, recreation, geology, archaeology and socio-economic development were conducted. (Forestry Annual Report 2015:55)}

The next element is the Forest Harvesting element which allows information regarding forest harvesting activities are presented in this section. Similar to the Forest Resource Development, information regarding the total number of areas that have been licensed for harvesting is presented in a table form, as shown in Figure 3. 


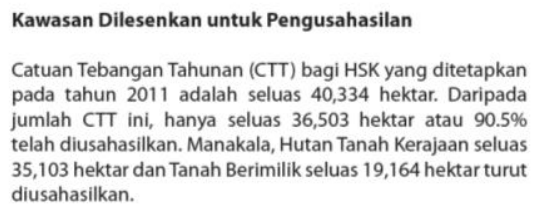

Area Licensed for Harvesting

The Annual Allowable Cut (AAC) prescribed for PRFs in 2011 was 40,334 hectares. Out of this AAC, only 36,503 hectares or $90.5 \%$ were harvested. Meanwhile, an area of 35,103 hectares of Stateland Forest and 19,164 hectares of Alienated Land were also harvested. diusahasilkan.

\begin{tabular}{|c|c|c|c|}
\hline \multicolumn{2}{|c|}{ Jenis Hutan / Forest Type } & Hektar / Hectares & Peratus / Percent (\%) \\
\hline \multirow{2}{*}{$\begin{array}{l}\text { Hutan Simpanan Kekal } \\
\text { Permanent Reserved Forest }\end{array}$} & $\cdot \mathrm{CTT}$ & 36,503 & 33.0 \\
\hline & - Luar / Outside CTT* & 19,750 & 17.9 \\
\hline $\begin{array}{l}\text { Hutan Tanah Kerajaan } \\
\text { Stateland Forest }\end{array}$ & & 35,103 & 31.8 \\
\hline $\begin{array}{l}\text { Tanah Berimilik } \\
\text { Alienated Land }\end{array}$ & & 19,164 & 17.3 \\
\hline Jumlah / Total & & 110,520 & 100.0 \\
\hline
\end{tabular}

Figure 3. Example of the Forest Harvesting element

Following the Forest Harvesting element is the Production element. In this element, readers are provided with information regarding the production of timber products. Once again, the information is presented in a visual form for ease of reference for the readers. Information regarding the production of timber products under the Production element is depicted in Figure 4.

\begin{tabular}{|c|c|c|c|}
\hline PENGELUARAN & \multicolumn{3}{|c|}{ PRODUCTION } \\
\hline \multicolumn{2}{|c|}{$\begin{array}{l}\text { Dalam tahun } 2016 \text {, pengeluaran hasil kayu terpilih } \\
\text { mencatatkan peningkatan iaitu kayu balak }(2.5 \%) \text {, } \\
\text { dan venier }(38.7 \%) \text {. Manakala pengeluaran kayu } \\
\text { gergaji, papan lapis dan kayu kumai mencatatkan } \\
\text { pengurangan masing-masing sebanyak } 1.1 \%, 14.5 \% \\
\text { dan } 9.3 \% \text {. }\end{array}$} & \multicolumn{2}{|c|}{$\begin{array}{l}\text { In } 2016, \text { the production of selected timber products } \\
\text { such as log }(2.5 \%) \text {, and veneer }(38.7 \%) \text { recorded } \\
\text { increases. Meanwhile, the production of sawn } \\
\text { timber, plywood and moulding recorded decreases } \\
\text { of } 1.1 \%, 14.5 \% \text { and } 9.3 \% \text { respectively. }\end{array}$} \\
\hline \multicolumn{4}{|c|}{$\begin{array}{l}\text { Pengeluaran Hasil Kayu Terpilih }\left(\mathrm{m}^{3}\right) \\
\text { Production of Selected Timber Products }\left(m^{3}\right)\end{array}$} \\
\hline $\begin{array}{l}\text { Industri } \\
\text { Industry }\end{array}$ & 2016 & 2015 & $\begin{array}{c}\text { Perubahan Tahunan } \\
\text { Annual Change 2016/2015 (\%) }\end{array}$ \\
\hline Kayu Balak / Log & $4,450,784$ & $4,340,614$ & 2.5 \\
\hline Kayu Gergaji / Sawn Timber & $2,484,569$ & $2,511,256$ & -1.1 \\
\hline Papan Lapis / Plywood & 364,247 & 425,796 & -14.5 \\
\hline Venier / Veneer & 93,854 & 67,688 & 38.7 \\
\hline Kayu Kumai / Moulding & 71,900 & 79,277 & -9.3 \\
\hline
\end{tabular}

Figure 4. Example of the Production element

The next element that precedes the Production element is the Wood-based Industries element. Under this element, reports regarding the forestry department's inspection on activities by furniture/woodworking/carpentry/ and joinery mills registered under FDPM are presented through a visual presentation in table form. The information presented under the Wood-based Industries element also helps to explicate the forestry department's monitoring activities to ensure these parties abide by the respective forestry governance standards and policies. Figure 5 illustrates the information presented under the Wood-based Industries element in the forestry annual report. 
Industri Berasas Kayu Terpilih

Selected Wood-Based Industries

\begin{tabular}{lc}
\hline \multicolumn{1}{c}{$\begin{array}{c}\text { Jenis Industri } \\
\text { Industry Type }\end{array}$} & $\begin{array}{c}\text { Bilangan } \\
\text { Number }\end{array}$ \\
\hline Kilang Papan / Sawmill & 633 \\
\hline Kilang Papan Lapis dan Venier / Plywood and Veneer Mill & 45 \\
\hline Kilang Kayu Kumai / Moulding Mill & 101 \\
\hline $\begin{array}{l}\text { Kilang Perabot/Kerja Kayu/Pertukangan dan Tanggaman* } \\
\text { Furniture/Wood Working/Carpentary and Joinery Mil/* }\end{array}$ & 528 \\
\hline Kilang Papan Blok / Blockboard Mill & 15 \\
\hline $\begin{array}{l}\text { Kilang Papan Serpai dan Papan Serpih } \\
\text { Chipboard and Particleboard Mill }\end{array}$ & 34 \\
\hline $\begin{array}{l}\text { Kilang Papan Gentian Sederhana Padat (MDF) } \\
\text { Medium Density Fibreboard (MDF) Mill }\end{array}$ & 48 \\
\hline * Merujuk hanya kepada Kilang Perabot/Kerja Kayu/Pertukangan dan Tanggaman yang berdaftar dengan JPSM & \\
\hline
\end{tabular}

Figure 5. Example of the Wood-based Industries element

Another element included in the forestry annual report under the Year under Review section is the Socioeconomic Contributions elements. In contrast to the elements presented thus far, which focus more on the statistical information of forest areas, timber products and the types of wood-based industries in Peninsular Malaysia, this element is concerned with providing details regarding contributions received from various areas that have been impacted upon as a result of the forest activities conducted throughout the year. Under the Socioeconomic Contributions, there are three sub-elements, including Timber Products Trade, Forest Revenue Collection to the State Government, and Employment in the Forestry Sector. Under the Timber Products Trade, details about export earnings from timber products are disclosed, as shown in Excerpt 5.

\section{Excerpt 5:}

In 2016, the total export earnings of Malaysian timber products recorded an increase of $0.9 \%$ to

RM21.9 billion as compared to RM21.7 billion in 2015. For Peninsular Malaysia, export of timber products amounted to RM5.78 billion, an increase of $7.6 \%$ compared to RM5.37 billion in 2015. (Forestry Annual Report 2016:58)

As for the Forest Revenue Collection to the State Government element, the total revenues are also presented to the reader, as presented in Excerpt 6. Information regarding the revenues gathered would provide information on the revenues to the government and state governments of the total earnings from forest-based products/activities.

\section{Excerpt 6:}

Forest revenues are derived from royalties, premiums, cess, forest offence fines, compensations and other charges/fees. The forest revenue contributed RM477.9 million to the state coffers in 2015.

The final sub-element of the Socioeconomic Contribution element is information regarding employment in the forestry discipline, which is presented under the Employment in the Forestry Sector element. Under this element, employment opportunities in various forestrelated sectors are presented in the forestry annual report highlighted in Figure 6. 


\section{Pekerjaan dalam Sektor Perhutanan}

Dalam tahun 2017, sektor perhutanan diSemenanjung Malaysia menyediakan sejumlah 35,682 peluang pekerjaan secara langsung dalam pelbagai industri seperti jadual di bawah. Ini mencatatkan penurunan keseluruhan sebanyak $0.8 \%$ berbanding 35,958 orang pada tahun 2016

\section{Employment in the Forestry Sector}

In 2017, the forestry sector in Peninsular Malaysia provided direct employment to 35,682 persons in the various industries as stipulated below. This registered an overall decrease of $0.8 \%$ as compared to 35,958 persons in 2016

Guna Tenaga Secara Langsung Dalam Sektor Perhutanan di Semenanjung Malaysia Total Direct Employment in the Forestry Sector in Peninsular Malaysia

\begin{tabular}{lccc|}
\multicolumn{1}{c}{$\begin{array}{c}\text { Jenis } \\
\text { Type }\end{array}$} & 2017 & 2016 & $\begin{array}{c}\text { Perubahan Tahunan (2017/2016) } \\
\text { Annual Change (2017/2016) } \\
\text { (\%) }\end{array}$ \\
\hline Pengusahasilan Hutan / Forest Harvesting & 6,417 & 7,524 & -14.7 \\
\hline Kilang Papan / Sawmill & 16,252 & 15,618 & 4.1 \\
\hline Papan Lapis / Venir / Plywood / Veneer & 5,129 & 5,325 & -3.7 \\
\hline Kayu Kumai / Moulding & 2,754 & 2,463 & 11.8 \\
\hline Penjawat Awam / Public Service & 5,130 & 5,028 & 2.0 \\
\hline Jumlah / Total & 35,682 & 35,958 & -0.8 \\
\hline
\end{tabular}

Figure 6. Example of the Employment in the Forestry Sector element

The final element that makes up the GSP of the Year under Review section in the forestry annual report is the Human Resource Development element. Unlike other sections of the Year under Review section, the Human Resource Development element exclusively presents the total number of training programmes forestry officers are involved in throughout the year. This information is also presented in visuals to ease the readers, as shown in Figure 7.

\begin{tabular}{|c|c|c|}
\hline $\begin{array}{l}\text { PEMBANGUNAN SUMBER } \\
\text { MANUSIA }\end{array}$ & \multicolumn{2}{|l|}{$\begin{array}{l}\text { HUMAN RESOUCE } \\
\text { DEVELOPMENT }\end{array}$} \\
\hline $\begin{array}{l}\text { Bagi memperkasakan lagi pembangunan sumber } \\
\text { manusia di JPSM, sebanyak } 118 \text { program latihan } \\
\text { dalam dan luar negara mengikut kategori seperti } \\
\text { yang ditunjukkan dalam jadual di bawah termasuk } \\
77 \text { program latihan yang dianjurkan oleh IPJPSM. } \\
\text { Sejumlah } 2,688 \text { penyertaan telah diterima dan dapat } \\
\text { memberi manfaat dalam pelbagai bidang seperti } \\
\text { kenegaraan, teknikal, pengurusan sumber manusia, } \\
\text { pembangunan kendiri, pengurusan kewangan, } \\
\text { teknologi dan kaunseling/psikologi sepanjang tahun } \\
2018 \text {. }\end{array}$ & \multicolumn{2}{|c|}{$\begin{array}{l}\text { To strengthen the development of human resource } \\
\text { in FDPM, a total of } 118 \text { training programmes both } \\
\text { at local and international level as shown in the table } \\
\text { below including } 77 \text { training programmes organised by } \\
\text { FDPMHq. A total of } 2,688 \text { participations had benefited } \\
\text { from the various fields such as nationhood, technical, } \\
\text { human resource management, financial management, } \\
\text { information technology and counselling/psychology } \\
\text { conducted throughtout } 2018 \text {. }\end{array}$} \\
\hline $\begin{array}{l}\text { Selain daripada itu, } 88 \text { orang pelatih bagi Kursus } \\
\text { Sijil Perhutanan Pengawas Hutan Sesi } 2017 / 2018 \\
\text { telah menamatkan latihan mereka di Institut Latihan } \\
\text { Perhutanan, Kepong (FORTRAIN) pada tahun } 2018 \text {. } \\
\text { Manakala, seramai } 78 \text { orang pelatih Kursus Sijil } \\
\text { Perhutanan Pengawas Hutan Sesi } 2018 / 2019 \text { dan } 19 \\
\text { orang pelatih Kursus Sijil Perhutanan Renjer Hutan } \\
\text { Sesi } 2018 / 2020 \text { masih menjalani latihan. }\end{array}$ & \multicolumn{2}{|c|}{$\begin{array}{l}\text { In addition, a total of } 88 \text { trainees of the Forestry } \\
\text { Forester Certificate Courses for the } 2017 / 2018 \text { have } \\
\text { completed their traning at the Forestry Training } \\
\text { Institute, Kepong (FORTRAIN) in 2018. Meanwhile, } \\
78 \text { trainees of the Forestry Forester Certificate Course } \\
\text { for the } 2018 / 2019 \text { and } 19 \text { trainees of the Forestry } \\
\text { Ranger Certificate Course for the 2018/2020 Session } \\
\text { are still in training. }\end{array}$} \\
\hline \multicolumn{3}{|c|}{$\begin{array}{l}\text { Program Latihan } 2018 \\
\text { Training Programme } 2018\end{array}$} \\
\hline $\begin{array}{l}\text { Jenis } \\
\text { Type }\end{array}$ & $\begin{array}{l}\text { Dalam Negeri } \\
\text { Local }\end{array}$ & $\begin{array}{l}\text { Luar Negeri } \\
\text { Overseas }\end{array}$ \\
\hline $\begin{array}{l}\text { Kursus/Lawatan Belajar } \\
\text { Courses/Study Tour }\end{array}$ & 48 & 0 \\
\hline $\begin{array}{l}\text { Seminar/Bengkel/Makmal } \\
\text { Seminar/Workshop/Lab }\end{array}$ & 8 & 15 \\
\hline $\begin{array}{l}\text { Persidangan/Konvensyen/Simposium/Kolokium } \\
\text { Conference/Convention/Symposium/Coloquium }\end{array}$ & 0 & 7 \\
\hline $\begin{array}{l}\text { Dialog/Forum } \\
\text { Dialogue/Forum }\end{array}$ & 7 & 1 \\
\hline $\begin{array}{l}\text { Ceramah/Syarahan Am/Taklimat } \\
\text { Talk/Speeches/Briefing }\end{array}$ & 3 & 0 \\
\hline Lawatan Belajar / Study Tour & 0 & 3 \\
\hline Ekspedisi / Expedition & 1 & 0 \\
\hline Lain-lain / Others & 10 & 15 \\
\hline Jumlah / Total & 77 & 41 \\
\hline
\end{tabular}

Figure 7. Example of the Human Capital Development element 


\section{Discussions}

Overall findings on the analysis of elements and GSP of the Year under Review of forestry annual report genre reveals that the main focus of the Year under Review of forestry annual report genre is to inform readers about the goings-on and updated information regarding various aspects of forestry-related issues as expounded by the nine elements analysed in the genre. All the nine elements observed in the Year under Review of forestry annual report genre are obligatory elements that are required to accomplish the function and structure of the genre. This suggests that the Year under Review of forestry annual report genre is highly standardised in which each element is present in all the ten datasets analysed. The GSP of the Year under Review of forestry annual report genre is formulated in a linear pattern aligned with the monologic nature of the text. As pointed earlier, all elements observed in the genre are obligatory elements that help accomplish its purpose. Only five embedded elements are found in two elements of the genre; the Forest Conservation and Environmental Protection (FCEP) and the Socioeconomic Contributions (SC) elements, while optional or recursive elements were not observed in the study. This indicates that all the elements are required to be included in the genre. Bhatia (2004) contends that professional report genres can be diverse and versatile in terms of their 'conceptualisation, specification and hybridisation, both in mixed and embedded forms' (Bhatia, 2004:83), which is particularly evident in the case of the Year under Review section of the forestry annual report genre. An interesting finding gained from the study is that the GSP of the Year under Review of the forestry annual report genre consists of only obligatory elements in which no optional or recursive elements are found in the genre analysed. This shows that all the elements found in the reports are required and must be included in order for the reports to achieve their purpose of informing the readers about relevant and updated information regarding forestrelated matters. Consequently, the GSP of the Year under Review of the forestry annual report genre derived from the analysis is reflective of the structural resources available within a genre as discussed by Hasan (1984) that can benefit forestry students to understand more about their future profession's requirements and expectations.

\section{Conclusion}

This study examines the GSP of forest annual report and contends that the elements of the GSP model have achieved the communicative and social purpose of the forestry annual report, which is to inform customers, staff, stakeholders and shareholders about the programmes and events that took place in the year under review. The text structure of the forestry annual report genre and its GSP have shed light on the instantiation of a specific set of choices from the GSP and the abstraction of the forestry annual report's semantic and lexicogrammatical features. While this study only focused on the unity of structure under which the GSP has been devised, it should be noted that further exploration concerning the potential use of GSP can provide valuable information to both practitioners and forestry students at the tertiary level on the various types of forestry discourses and the forestryrelated agendas that can be represented through these discourses. The GSP of the forestry annual report genre investigated in this study is therefore deemed to have high educational and pedagogical value, particularly to students enrolled in the tertiary level's forestry programmes. Understanding insights of the common professional forestry text such as the annual report allows a better understanding of the kind of information appropriate to be learned and disseminated in the context of sustainable forest management practices and forest discourse. 


\section{Limitations and Future Studies}

This study only explored one of the sections included in the forestry annual report issued by FDPM. Therefore, a complete representation of the annual report genre in the forestry discipline could not be derived. Thus, the researchers are attempting to analyse similar or more relevant information that can better represent the structure and texture of the forestry annual report genre. Future research interested in uncovering more instantiation and representation of forestry discourse can apply the GSP model proposed in this study to enrich knowledge and increase awareness of forestry-related texts among forestry students and practitioners.

\section{Acknowledgement}

The authors would like to thank the Ministry of Higher Education and Universiti Teknologi Malaysia for the funding received under the Fundamental Research Grant Scheme (Vote No: FRGS/1/2019/SS09/UTM/03/1) to support this study.

\section{References}

Ansary, H., \& Babaii, E. (2005). The generic integrity of newspaper editorials: A systemic functional perspective. RELC Journal. 36(3), 271-295.

Bowcher, W. L., \& Liang, J. Y. (2016). GSP and multimodal texts. In Society in Language, Language in Society. (pp. 251-274). Palgrave Macmillan, London.

Muda, C. H. C., Hamat, C., \& Yusoff, M. K. (2009). Natural resources management towards the sustainable development in Lojing, Gua Musang, Kelantan. In Proceedings of postgraduate colloquium. Faculty of Enviromental Studies, Universiti Putra Malaysia. de Jong, W., Galloway, G., Katila, P., \& Pacheco, P. (2017). Forestry discourses and forestbased development - An introduction to the special issue. International Forestry Review. 19(1). 1-9.

Eggins, S., \& Martin, J. R. (1997). Genres and registers of discourse. In T.A. van Dijk (ed.). Discourse as Structure and Process. London: Sage Publications. 230-256.

Eggins, S. (2007). An introduction to Systemic Functional Linguistics. Second Edition. London: Continuum.

Fairclough, N. (2003). Analysing discourse: Textual analysis for social research. Psychology Press.

Friginal, E. (2013). Developing research report writing skills using corpora. English for Specific Purposes, 32(4). 208-220.

Halliday, M. A. (1990). The place of dialogue in children's construction of meaning. ERIC Clearinghouse.

Halliday, M. A. K. (1978). Language as social semiotic: The social interpretation of language and meaning. London: Edward Arnold.

Halliday, M. A. K. (2004). An introduction to functional grammar. 3rd edition. London: Hodder Education.

Halliday, M. A. K., \& Hasan, R. (1985). Language, context and text: Aspects of language in a social-semiotic perspective. Oxford: Oxford University Press.

Hasan, R. (1984). The nursery tale as a genre. Nottingham Linguistic Circular, 13, 71-102.

Hasan, R. (1985). Language, linguistics and verbal art. Oxford: Oxford University Press.

Hasan, R. (2014). Linguistic sign and the science of linguistics: The foundations of appliability. In Fang Yan and J.J. Webster (eds.). Developing Systemic Functional Linguistics: Theory and Application. Sheffield: Equinox Publishing. 106-137. 
Hussain, S. S., Ali, A. M., Kasim, Z. M., \& Jalaluddin, I. (2020). A review on the rhetorical structure and Inguistic features of corporate annual reports. International Journal of Academic Research in Business and Social Sciences. 10(9). 237-256.

Hyland, K. (1998). Exploring corporate rhetoric: Metadiscourse in the CEO's letter. Journal of Business Communication. 35(2), 224-244.

Islam, R., Siwar, C., Ismail, S. M., \& Chamhuri, N. H. (2010). Criteria and indicators for sustainable forest management in Malaysia. American Journal of Environmental sciences. 6(3), 212. ITTO. (1999). Annual Report for 1999. Lima: ITTO.

Jalilova, G., Khadka, C., \& Vacik, H. (2012). Developing criteria and indicators for evaluating sustainable forest management: A case study in Kyrgyzstan. Forest Policy and Economics. 21. 32-43.

Joseph, R., \& Lim, J. M. H. (2018). Background information in the discussion sections of forestry journals: A case study. GEMA Online Journal of Language Studies. 18(1). 198216.

Joseph, R., Lim, J. M. H., \& Nor, N. A. M. (2014). Communicative moves in forestry research introductions: Implications for the design of learning materials. Procedia-Social and Behavioral Sciences, 134, 53-69.

Kong, K. (2014). Professional discourse. Cambridge: Cambridge University Press.

Leipold, S. (2014). Creating forests with words - A review of forest-related discourse studies. Forest Policy and Economics. 40. 12-20.

Longacre, R. E. (1992). The discourse strategy of an appeals letter. Discourse Description: Diverse Linguistic Analysis of a Fund-Raising Text. Ed. William C. Mann and Sandra A. Thompson.

Malmkjær, K. (2009). The Routledge linguistics encyclopedia. London: Routledge.

Martin, J. R. (1984). Language, register and genre. In F. Christie (ed.) Language Studies: Children's Writing: Reader. Geelong: Deakin University Press.

Gani, I. Q. L. M., Wahab, R., \& Rasat, M. S. M. (2013). An overview of illegal logging situation in Peninsular Malaysia. Journal of Tropical Resources and Sustainable Sciences. 1(2). 2430.

Zukki, N. I. M., Manaf, L. A., \& Samah, M. A. A. (2010). The development of an expert system for decision making in forest resources management. Environment Asia. 3. 98-102.

Morley, G. D. (1985). An introduction to systemic grammar. Macmillan.

Paltridge, B. (1994). Genre analysis and the identification of textual boundaries. Applied Linguistics. 15(3). 288-299.

Rothery, J. (1996). Making changes: Developing an educational linguistics. In R. Hasan and G. Williams (Eds.) Literacy in society. London: Longman. 86-123.

Schleppegrell, M. J. (2012). Systemic functional linguistics: Exploring meaning in language. In James Paul Gee and Michael Handford (Eds.), The Routledge Handbook of Discourse Analysis. New York: Routledge. 21-34.

Swales, J. M. (1990). Genre analysis. English in academic and research settings. Cambridge: Cambridge University Press.

Van Dijk, T. A. (1977). Semantic macro-structures and knowledge frames in discourse comprehension. Cognitive processes in comprehension. 332. 3-31.

Wenger, E. (1998). Communities of practice: Learning, meaning, and identity. Cambridge: Cambridge University press. 
INTERNATIONAL JOURNAL OF ACADEMIC RESEARCH IN BUSINESS AND SOCIAL SCIENCES

Vol. 11, No. 7, 2021, E-ISSN: 2222-6990 @ 2021 HRMARS

Zanola, A. (2010). The annual report: An interdisciplinary approach to 'contaminated' new genre. Conference proceedings on "Genre on the move: hybridisation and discourse change in specialised communication. Paper 109. 1-28. 